\title{
雪舟による四季山水図巻の空間構成 THE SPATIAL COMPOSITION OF TWO LANDSCAPES OF THE FOUR SEASONS DRAWN AS HANDSCROLL BY SESSHU
}

\author{
真木 利 江*，和田 佳奈美**
}

Rie MAKI and Kanami WADA

\begin{abstract}
The aim of this paper is to clarify the spatial composition of Short Scroll of Landscapes and Long Scroll of Landscapes drawn by Sesshu. We divided these long handscrolls into mountainous scenes and horizontal ones, and these were classified into five types based on an analysis of spatial composition. Through the comparison of two handscrolls, the followings were made clear: 1) the fundamental composition of both scrolls shows strong resemblance. 2) Long Scroll of Landscapes has more contrasted composition between mountain and horizontal scenes, and more systematic construction of four seasons.
\end{abstract}

Keywords : Sesshu, Landscape Paintings, Spatial Composition, Type 雪舟, 山水画，空間構成，類型

\section{1.はじめに}

本研究は、室町期に描かれた山水図に当時の理想的風景の型を想 定し、これを抽出することを企図する研究の一端に位置づけられる。 本稿では雪舟 (1420-1506 頃) の真筆とされている 2 つ四季山水図 巻を対象とし、そこに描かれる山水の空間構成の特徴を明らかにす ることを目的とする。

わが国には絵と詞で物語を織りな寸物語絵巻を初め、宗教、文学、 記録・世相を主題とする巻子装の絵巻が多数現存している注 11 。一方、 鎌倉期以来、日本にもたらされた山水画は禅林を中心に受容され発 展をみるが、巻子装をもつ山水図はきわめて少ないことが知られて いる注 2)。本稿では雪舟の真筆とされる巻子装の四季山水図巻である 京都国立博物館所蔵の四季山水図巻 (重要文化財、以下山水小巻) と毛利博物館所蔵の四季山水図巻 (国宝、以下山水長巻、1486 年) の 2 巻を対象とするが注 3 )、いずれも室町期を代表する希少な山水図 巻である。

雪舟に関しては、明治期以降、美術史分野を中心に膨大な研究が 蓄積されてきたが、とくに山水長巻は数多くの模本が示すとおり、 江戸期にはすでに特別な作品として認識され、現在も雪舟の最高傑 作のみならず日本水墨画の代表作と位置づけられ研究が重㸚られて いる。跋文から夏珪との関連が古くから指摘されてきたが、とくに
近年では具体的な作品に即して形や意味の継承の様態が明らかにさ れつつある注 4)。また、山水長巻の全体構成を雪舟自身の人生や禅宗 の理念と結びつける等、多様な研究・言説が存在している注 ${ }^{5)}$ これ に比して山水小巻については山水長巻と比較したときの筆致の弱さ もあり、まとまった先行研究がほとんど存在しないという対照的な 扱いとなっている注 6)。いずれにせよ、これら 2 つの四季山水図巻に ついて、作品自体の空間構成を問うまとまった研究は存在せず、ま た山水小巻と山水長巻の全体像を直接比較する研究も存在しない。

\section{2. 研究の方法}

山水小巻と山水長巻の概要 : 本稿で対象とする 2 巻は山水小巻が縦 幅 $21.5 \mathrm{~cm}$ 、全長 $1151.5 \mathrm{~cm}$ (約 $1: 53.6$ )、山水長巻が縦幅 $39.2 \mathrm{~cm}$ 全 長 $1580.2 \mathrm{~cm}$ (1:41.5) といずれも横長の長大な構図をもつ(図 1 )。 一般に巻子装の作品は、一挙に全体像を眺めることの出来る掛幅装 とは異なり、鑑賞者が自らの手でひもとき肩幅程度に画面を繰り広 げ、その開閉を繰り返しながら展開させてゆくという独特の鑑賞方 法となる。当時の一般的な巻子の縦幅に対して、山水小巻はやや小 振りで手になじみやすい寸法であり、鑑賞者自身が巻物を繰ること を想定して制作されたと考えられている注7)。これに対して山水小巻 の倍近い縦幅を持つ山水長巻は、一般的な巻子の鑑賞とするには疑
* 山口大学大学院理工学研究科 講師·博士 (工学)

** 竹中工務店 工修
Lecturer, Graduate School of Science and Eng., Yamaguchi Univ., Dr. Eng. Takenaka Corporation, M. Eng. 


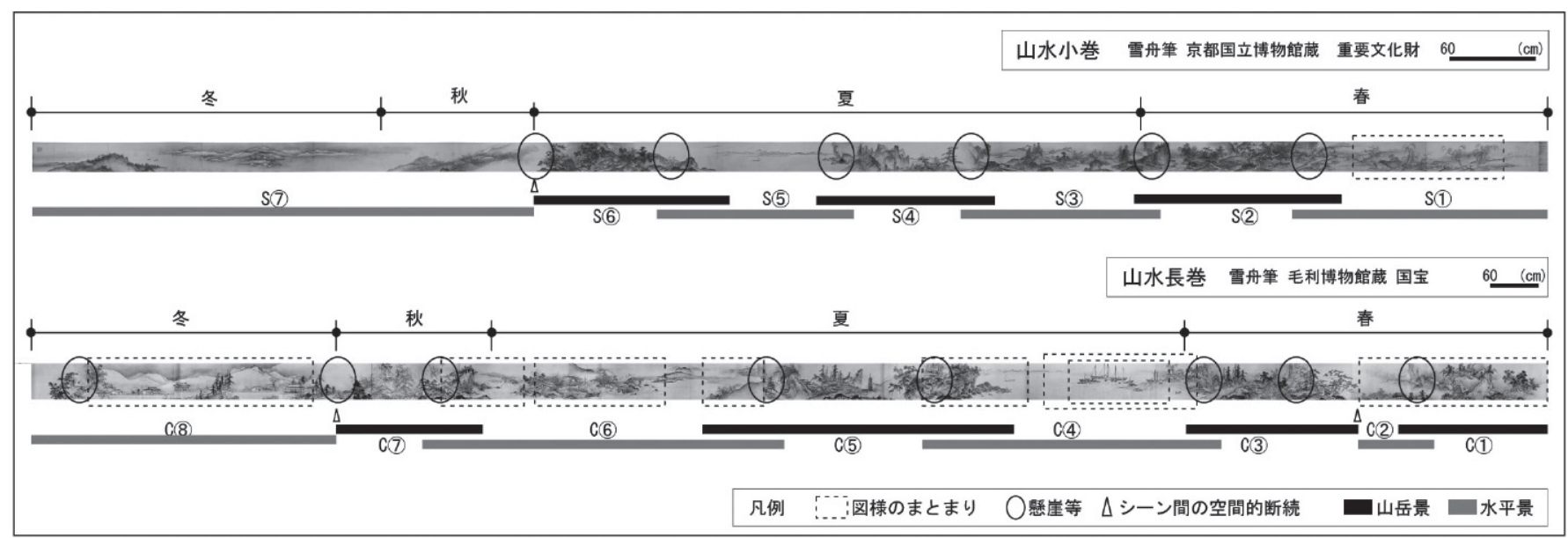

図 1 山水小巻と山水長巻のシーン区分

問があり、鑑賞自体の有無を含め鑑賞形式についてのまとまった見 解を見ることができない注 8 。

また、いずれも四季山水図巻であり、春から夏、秋、冬を経てふ たたび春の始まりへと季節が移り変わる構成をとる。画中に季節を 表すモチーフがちりばめられており、現実の季節同様に切り替わり の明確なラインが存在する訳ではないが、春夏秋冬のおおよその展 開を理解することが出来る注 9)。いずれも広く水面をたたえる夏景が 最も長く、春景と冬景はほぼ同じ長さでこれに続き、秋がもっとも 短いという構成を見せており、巻子全体に対する季節の配分は両巻 ともほぼ同じである。

本稿では、両巻の空間構成の特徴を明らかにするが、近年、美術 史の分野において素材空間または空間ユニットと呼ばれる、これら の作品が継承している意味を伴う図様のまとまりが指摘されている 注 10)。しかし、単にモチーフを収集することだけでは、全体を構成 することは出来ず、制作者による全体の構想があってはじめて長大 な巻子は完成を見ることができるといえよう。本研究の分析は、そ れぞれの作品には雪舟という制作者による全体構想があるというこ とを前提としている。

分析の流れ：両巻の全体像を概観すると、いずれも切れ目なく山水 が連続するというより、いくつかの地形のまとまりをもって骨格が 構成されているといえる。本稿では、四季山水図巻の空間構成の特 徵を明らかにするため、画巻の寸法と鑑賞形式の相違、意味を伴う 図様のまとまりについてはいったん問題を保留し、地形のまとまり を手がかりに全体をいくつかのシーンへと区分し、シーンの連続と して全体を捉え直す。

シーンの区分においては、巻子の縦幅に収まりきらない巨大な岩 山の存在が、岩山の一部が描かれることで示唆されている箇所（以 下、懸崖等）に注目するが、この表現のほとんどに両巻に共通して 下部が抉れた懸崖という同じモチーフが使用されている注 11$)$ 。た、 両巻を観察すると、懸崖等に両側を挟まれた部分とそれ以外の部分 では、山水の姿に明確な相違があるといえる。つまり、前者は主に ＜山岳景〉となっており描かれる川も細く急であるのに対して、そ れ以外の部分は左右に広がる水辺等、左右にゆるやかに連続する要 素により構成されるく水平景＞となっている。本稿では、こうした 2 種類の景の対照を巻子の全体構成の骨格と捉え、これにもとづい
て分析を進めていく。シーンの区分を図 1 に示寸が、山水小巻が山 岳景 3 シーン、水平景 4 シーンの計 7 シーン、山水長巻が山岳景 4 シーン、水平景 4 シーンの計 8 シーンで構成されており、それぞれ 右から順にシーン名称を S(1)-S(7)、C(1)-C8 とする。シーン区分に おいては、地形のまとまりという観点から山岳景では懸崖等および これに重なる岩山を含め、水平景は懸崖等までを含め両者が重なる 形で区分するが、空白表現によりシーン間の空間的断続が明瞭な $\mathrm{S}$ (6)-(7)、C(2)-(3)、C(7)-(8)は空白部で切断する形で区分する。

分析の大まかな流れとしては、まず 2 巻の全 15 シーンを対象に 空間構成の特徵を明らかにし、つぎに巻子の全体構成についてシー ンの並びや空間構成の対応関係から 2 巻の比較を行う。最後に巻子 の空間構成について鑑賞という観点から考察を加える。

\section{3. シーンの空間構成}

3-1 分析の方法 : ここではシーンの空間構成の特徴を明らかにする ため、まず 2 巻にみられる山水の構成要素を確認する。その後、シ ーンごとに構成要素の配置の様相を三次元的な広がりのなかに捉え なお寸とともに、それらによって空間に与えられている方向性を抽 出する。これらをもとに、空間構成の類型化を試みる。

$<$ 構成要素 $>$ 山水の構成要素はおおきく地形、植物、人為的要素に 区分することができる。地形は山や谷などの地面の起伏と水面であ り、川、滝、洲浜、岩等も含まれる。こうした地形のひろがりに樹 木や樹林、灌木といった植物、人為的要素が点在する。人為的要素 には人物、道、建物、舟、橋等が含まれる。

<配置の様相 > 構成要素の配置の様相を三次元的な空間の広がりに とらえなおすため、それぞれのシーンに描かれる空間全体を、前後・ 左右・上下つまり、奥行・水平・垂直の 3 方向を持つ幾何学的な空 間の広がりとしてとらえ、構成要素の配置の様相を、全体の空間内

表 1 分析指標

\begin{tabular}{|c|c|c|c|}
\hline \multirow{3}{*}{ 構成要素 } & 地形 & 山、水面、川、谷、滝、州浜、岩 & \multirow{8}{*}{ 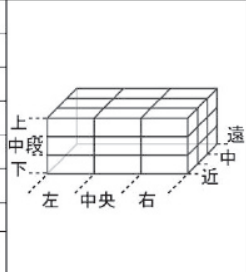 } \\
\hline & 植物 & 樹木、樹林、灌木 & \\
\hline & 人為的要素 & 人物、道、建物、舟、橋 & \\
\hline \multirow{4}{*}{ 配置の様相 } & \multirow{3}{*}{ 位置 } & 奥行 : 近景 / 中景 / 遠景 & \\
\hline & & 水平：左 / 中央 / 右 & \\
\hline & & 垂直 : 上/中段 /下 & \\
\hline & 様相 & 連続 / 断続 & \\
\hline 空間の方向性 & 奥行 : 奥行 & 感、水平 : 広がり感、垂直 : 上昇感 & \\
\hline
\end{tabular}


で相対的にとらえなおす。奥行方向は近景／中景／遠景、水平方向 は左／中央／右、垂直方向は上／中段／下へそれぞれ区分し、連続 ノ断続の様相を確認し、アイソメトリック図法により模式的に表現 していく。

<空間の方向性>各シーンには構成要素の配置によって、空間の垂 直、水平、奥行の 3 方向に対応する上昇感、広がり感、奥行感とい った動きのある方向性が与えられる。画面構成という点からは樹木 や人為的要素によっても方向性は与えられるが、シーンの空間構成 という観点から、山水の骨格をな寸地形に注目し、シーンにおいて 卓越する地形による空間の方向性を抽出し模式的に表現する。

以上の分析指標を表 1 にまとめて示す。

3-2 分析：ここでは山水小巻の冒頭のシーン S(1)ついて図 2 に模 式図等を示しながら報告し、他のシーンについては配置の様相およ び空間の方向性の模式図のみを図 3,4 にまとめて示寸注 ${ }^{22}$ 。

<配置の様相 > 全体に左右に連続する水平性の強い地形により構成 されている。陸地と水面の関係はやや複雑で、とくに近景中央の岩 山と左側の懸崖手前の岩山が、地形の空間的関係を不明瞭にしてい る。川が右遠景から左手前方向へゆるやかに連続し、中央近景の岩 山に隔てられ、左側近景からやや左斜め奥へと連続している。左右 端の近景にも水面が広がっている。右側の陸地は水面との間を右端 奥から左手前へと連続するが、最奥部には樹林がぼんやりと描かれ、 中景あたりから道が現れる。近景には柳の木が 3 本たちあがり、樹 下に驢馬にのる高士と荷物を担ぐ童子、行く先を示寸人物の 3 名が 描かれている。中央の中景から遠景へかけては緩やかな陸地が中央 でせり出す形で連続するが、右側は霞がかかり、左端の川沿いには 樹木と建物が描かれている。右方からの道が橋を経て川沿いを連続 し、左奥の樹林一消えていく。近景中央の岩山は平板な形状でやや 左上方へはりだし柳や梅の木を頂いており、その背後の様子は不明 瞭である。左端には懸崖が描かれ、その右下を懸崖にそって左奥へ と回り込む道が配されている。懸崖手前の岩山も平板で特徵的な形 態を示すが、右奥へと張り出した最奥部に二本の梅の木と樹下の 3 名の人物、ここへ至る近景からの道が描かれている。

<方向性 > 水面が右奥から手前へさらに左奥へと、断続しながらも

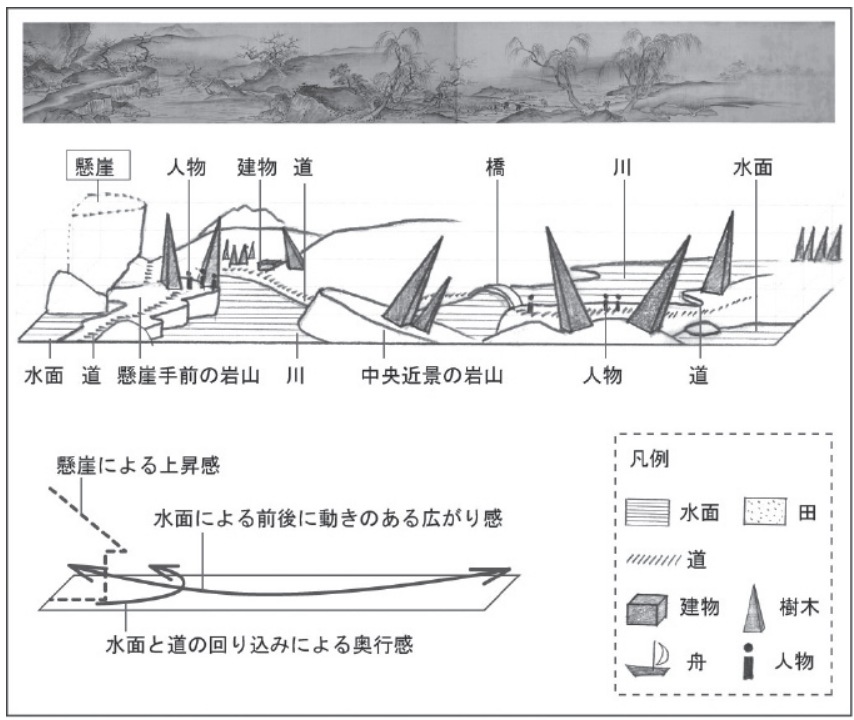

図 2 構成の配置と様相 (S(1)/ 水平景)
緩やかにつながることで、前後に動きのある水平方向の広がり感が 卓越する。左端では賏崖による上昇感とともに、これを左奥へと回 り込む方向性も与えられている。

3-3 空間構成の類型: 山水長巻と山水小巻の全 15 シーンそれぞれに ついて構成要素の配置の様相を明らかにし、それによって与えられ る空間の方向性を抽出した。両巻子の山岳景計 7 シーン、水平景計 8 シーンのそれぞれについて、卓越する空間の方向性に注目しシー ンの分類を行う。まず山岳景ではシーン中央に示唆される岩山によ って強い上昇感が共通して与えられるが、中央の岩山に洞穴が穿た れることで一体的な奥への方向性が与えられている<山岳景囲繞型 $>$ と、中央の岩山の前面に配される構成要素により岩山の上昇性と は断続する深い奥行き感が与えられている<山岳景断続型 $>$ 、中央 の岩山手前に同じく巨大な岩山が重衫られることで巨大な岩山によ る方向性が二重に与えられるく山岳景重層型 $>$ に分して捉えるこ とができる。次に水平景では近景から遠景までが階層状に構成され ることで強い水平性が強調されるく水平景階層型＞と、水平方向の 連続性が右奥から手前中央へ、さらに左奥へとうねるように連続す るく水平景ラウンド型 $>$ とに区分して捉えることができる。

これら各区分に該当するシーンを一覧表として表 2 に示し、分類 ごとに構成要素の配置の椂相について共通性を確認し、アイソメト リック図法によりモデル化を試みることで、空間構成の類型として 捉え直す。また、それぞれの類型においてとくに強い類似性を示す シーンを確認していく。

山岳景囲繞型：シーン中央部に、岩山で囲われたまとまりのある空 間を持つもので、これにより、中央の岩山による上昇感と一体的な 奥行き感が与えられるシーンで S(6) と C(7)が該当する。C(7)の右側に は懸崖が示されるが、いずれも洞穴を囲う岩山が部分的に表現され ることで、中央の巨大な岩山が示唆されている。右側は水面で、中 央の巨大な岩山の右手前に頂部に樹木を頂き水面側へと張り出す岩 山が配され、この付近に人物が描かれている。中央の岩山で囲われ た空間は洞穴状になっており、内部に建築物が配され人物が描かれ るが、川や道によってさらに洞窟の奥へと空間が連続する。また洞 穴上部では樹木が屈曲する。空間の左手前には建築的要素が配され、 その左側には岩山と樹木が配される。いずれも左端の樹木の背後は 霞がかかった不明瞭になっており、次シーンとの間は断続的である。 S(6) と C(7)は空間構成としては強い類似性を示しているといえる。

山岳景断続型: 中央の岩山の前面に配される構成要素によりシーン 中央部で深い奥行き感が与えられる構成を持つもので S(2)(4)、C(3)(5) が該当し、す心゙てのシーンで両側が懸崖となっている。右側の懸崖 下にはすべて崖道が手前から左奥へと回り込み、懸崖手前には岩山 と樹木が配される。右側の地形は C(3)をのぞく 3 シーンで水面とな っている。左側懸崖の左はすべて水面となっているが、懸崖の手前 には左下から右へと高さを増す岩山が配され付近に樹木群が垂直に 伸びる。中央部では構成要素の重なりや、奥へと連続する地形によ り深い奥行きのある空間が構成されているが、いずれも中景付近に 建築的要素が配される。この中央部の空間構成は、S(4)とC(5)の間に 強い類似性が認められる。いずれも右側の懸崖の左側に空白があり、 空間的な断絶が示されており、ここへ左側に重心を置いて重ねられ る岩山の最奥部が連続する。S(2), C(3)はいずれも中央部において細長 い形状を持つ川や谷などが奥へ連続する構成では共通するが、S(2)で 


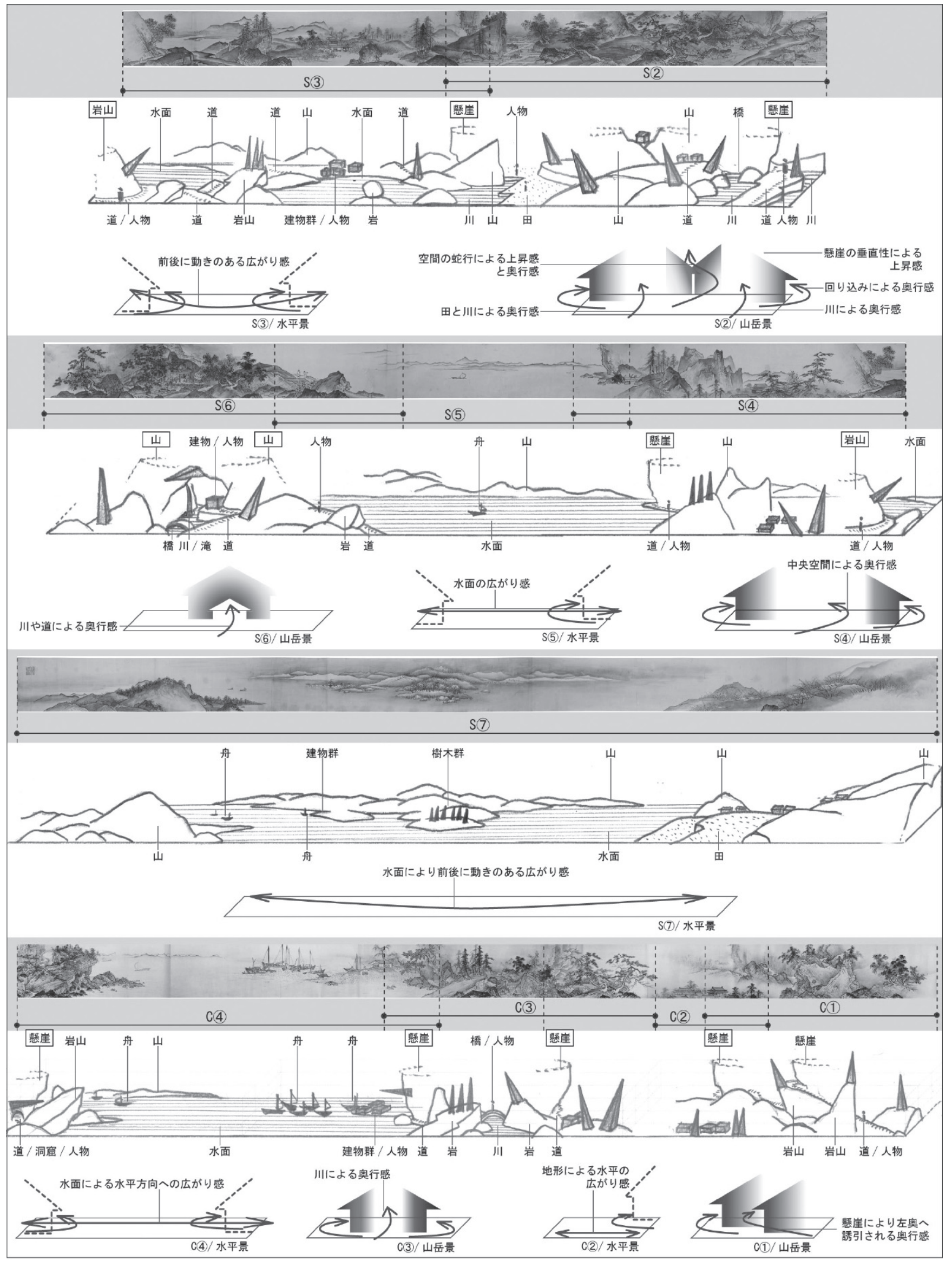

図 3 構成要素の配置の様相と空間の方向性（S(2)-S(7), C(1)-C(4) 


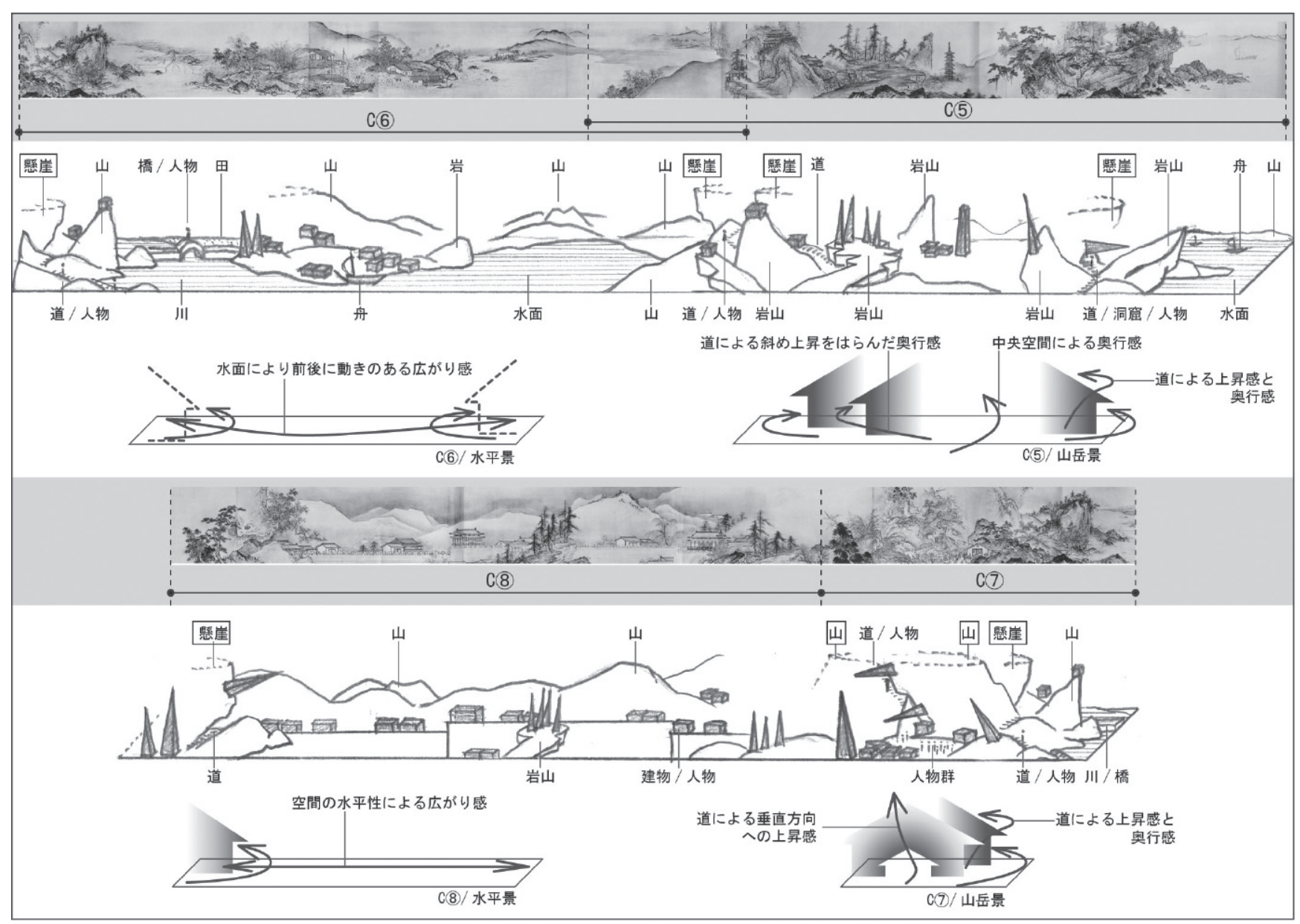

図 4 構成要素の配置の様相と空間の方向性（C5)-C8)

表 2 空間の方向性による分類と空間構成の類型

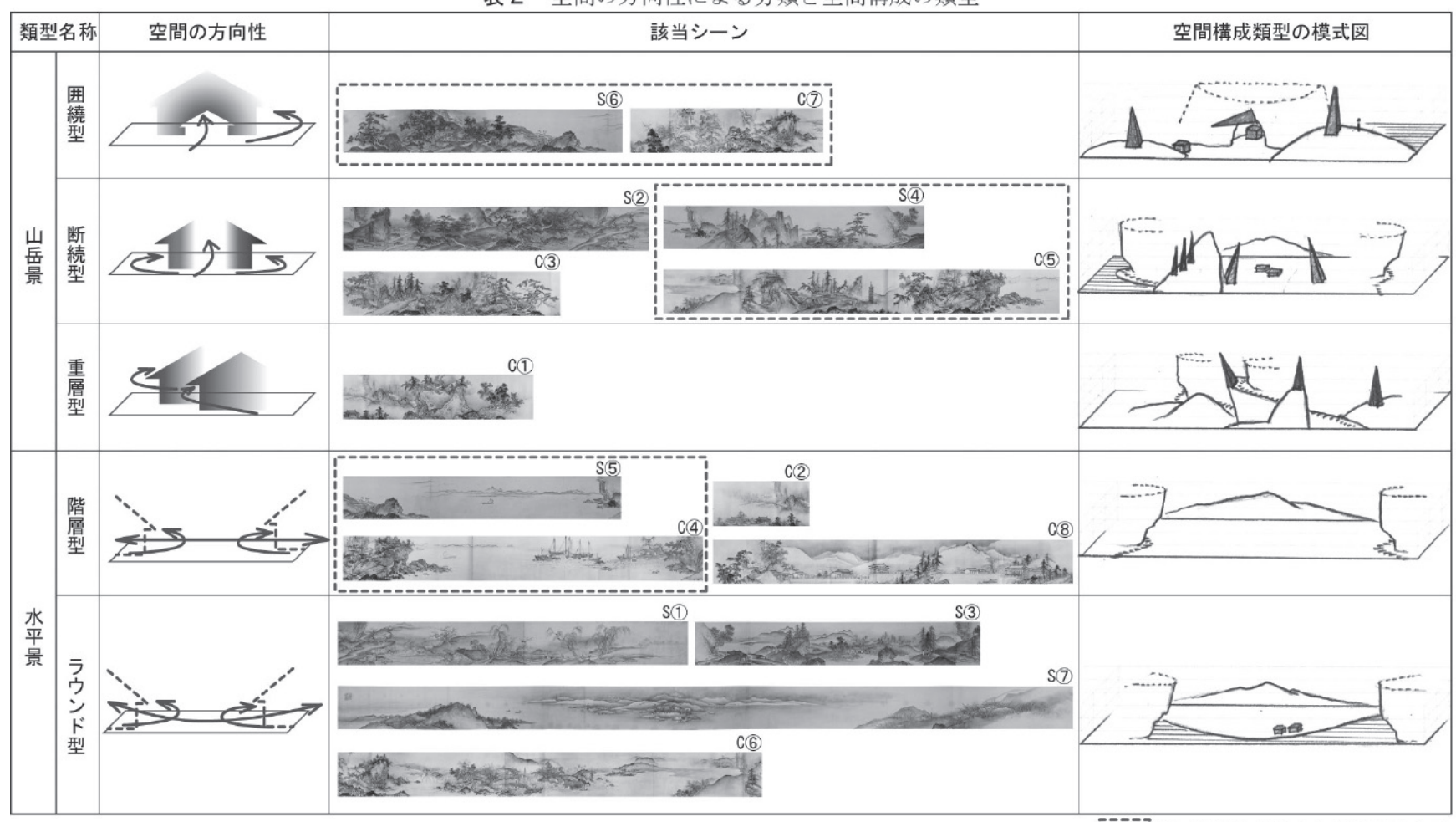

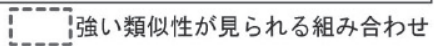


はこうした構成が複数回繰り返されることで C(3)に比して複雑な様 相を見せる。

山岳景重層型：中央の巨大な岩山の前面に同じく巨大な岩山が重な れることで、二重に強い上昇性が与えられるもので C (1)のみが該当 する注 ${ }^{13)}$ 。それぞれの岩山に上昇しながら奥へと回り込む道が配さ れることで、上昇しながら岩山を回り込む方向性も与えられている。

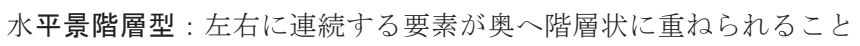
で水平性が強調されるもので、S(5), C(2)(4)(8)が該当するが、このうち S(5), C(4) は強い共通性が認められる。近景から遠景まで連続する広大 な水面が左右に広がり舟が浮かべられ、最奥部が遠景の山並みのシ ルエットで境界づけられている。またともに右端で水面から立ち上 がる懸崖下に崖道が奥へと連続しており、懸崖の前後両方へ水面が 連続する。左側の懸崖からは懸崖手前の岩山が水面に張り出す構成 を持つ。一方 C(2)と C (8)はいずれも描かれる風景が水面を含まない山 中の特徴的なシーンであり、片側は断続的である。

水平景ラウンド型：水平方向の連続性が右奥から手前中央へ、さら に左奥へとうねるように連続するもので、S(1)(3)(7)、C(6)が該当する。 いずれもなだらかな陸地と水面により構成されるが、うねるような 連続性は水面により与えられている。中央で張り出した地形には建 築的要素が配される。懸崖等との接続においては、水面が懸崖等の 背後に回り込む形で空間的に連続するが S (7)は断続を見せる。また 4 シーンのうち S(1)(3)全体の地形構成がやや複雑である。

\section{4. 全体構成 : 山水小巻と山水長巻の比較}

雪舟による 2 つ四季山水図巻を、山岳景と水平景に区分し、全 15 シーンから 5 つの空間構成類型を抽出するとともに、類型ごとに シーン間の類似性について確認した。ここでは、図 5 にシーン分析 において抽出した卓越する方向性を連続して表現するとともに、空 間構成類型および類型内で見出された強い類似を示すシーンの対応 を示し、ぞれぞれの巻子の全体構成をシーンの連続として捉え直し た後、2 巻の比較を行う。

まず山水小巻では、山岳景と水平景の繰り返しが S(1)-S(6)まで、 ほぼ均等な長さで連続する。この 6 シーンの類型は、はじめにく水 平景ラウンド型 $>$ から $<$ 山岳景断続型 $>$ という並びで 2 回繰り返さ れ、その後に<水平景階層型 $><$ 山岳景囲繞型 $>$ が連続する。巻末 は突出して長いく水平景ラウンド型 $>$ にり締めくくられる。 $\mathrm{S}(6)$ から S(7) のの移行部では、空白によってシーン間の断続が示されて いるが、その他では、水平景の水面が山岳景の背面に回り込むこと で連続的なシーン展開が行われている。

山水長巻では、冒頭部 C(1),(2),(3)で<山岳景重層型 $><$ 水平景階 層型 $><$ 山岳景断続型 $>$ と比較的短いシーンが繰り返される。その 後 $\mathrm{C}$ (4)から $\mathrm{C}$ (7)までが $<$ 水平景階層型 $><$ 山岳景断続型 $><$ 水平景 ラウンド型 $><$ 山岳景囲繞型 $>$ と、それぞれ異なる 4 種類の類型が 並び、最後は $\mathrm{C}$ (8)＜水平景階層型＞に終わる。C(2)から(3)人、C(7)か ら (8)への移行において空白表現により断続が示されるが、その他で は山水小巻と同様に水平景が山岳景の背後に連続するシーン転換が 行われている。

山水小巻と山水長巻の比較 : 2 巻の間には様々な相違が認められる 一方、明確な類似も指摘することが出来そうである。ここでは、雪 舟が山水長巻の構想を練る際、以前に描いた山水小巻を念頭に置い
ていたという仮定にたち、山水長巻が山水小巻から継承している点 と修正した点という観点から、両巻の類似点と相違点を整理する。

まず全体構成としては、山岳景と水平景の繰り返し、および山岳 景の背後に水平景が連続する形でのシーン転換という基本的構成が 継承されているといえる。

シーンの空間構成類型の順列について確認すると、まず山岳景の 類型配置は冒頭の C (1)を除くと、強い類似性を示すシーン間の関係 を含めて全く同一の形で踏襲されている。つまり、S(2)が C(3)に、 $\mathrm{S}$ (4)が C(5)に、そして S(6)が C(7)に対応している。対応関係ごとに変 更点を確認すると、 $\mathrm{S}(2), \mathrm{C}(3)$ は < 山岳景断続型 $>$ のち、細長い空 間が奥へ連続する点で共通していたが、C(3)では S(2)において複数 見たれた奥への方向性が一つに整理され、右側の水平景と間が断続 的関係に変更されている。 S(4),C(5)は＜山岳景断続型 >のうち、左 に重心を置く岩山群の遠景が右側䀣崖左の空白へ連続する構成にお いて強い類似性を示していたが、C(5)では両側の懸崖付近にそれぞ れ複雑な岩山が加えられ、䀣崖奥へと回り込む空間が立体感を増す 構成をみせる。最後に S(6), C (7) は強い類似性を示す<山岳景囲繞型 >であるが、空間構成は継承したまま画題が変更されるとともに注 14)、右側の懸崖が明瞭に描かれ前面に岩山が重衫られることで立体 化する。3つの山岳景において明瞭な対応関係が見られる一方、冒 頭の $\mathrm{C}(1)$ は唯一の<山岳景重層型>であり、水平景に始まる山水小 巻と異なった考え方で構成されているといえる。

一方、水平景は、両巻ともに 4 シーンであるが<水平景階層型 $>$ が S(5)から C(2)(4)(8)、＜水平景ラウンド型>はS(1)(3)(7)から C66 へと空間構成類型の該当数が反転し、山水長巻では山岳景との対照 がより明瞭なく水平景階層型＞が主になっている。 $\mathrm{S}$ (5) と C(4)の間 には強い共通性が認められるものの、全体に類型配置には大幅な変 更が加えられ、さらに山水長巻においては C(2)(8)で山中の水平景が 加えられることで、4つの水平景がそれぞれに特徴的な構成を示す 点も注目される。

最後に全体に対するシーンの配分を季節と対応させながら比較す ると、山水小巻では春 : S(1)(2)、夏 : S(3)(4)(5)(6)、秋冬 : S(7)となっ ており、春夏景ではほぼ同じ長さのシーンが、空間的に連続しなが ら繰り返され、秋冬景の突出して長い S (7)が断続する。これに対し、 山水長巻では春 : C(1)(2)(3)、夏：C(4)(5)(6)、秋：C(7)、冬：C(8)とな っており、春景は断続的なシーン転換を含む山中の短い 3 シーンが 繰り返され、夏景では長い 3 シーンが深く重なりながら連続的に続 き、短い秋景がこれに続く。その後断続して長い山中の冬景で終わ る。緩やかに連続する広い水面は夏景のみで描かれ、春秋冬景は山 中のシーンのみで構成されている。山水長巻ではそれぞれの季節が シーンの長さと連続・断続関係において特徴付けられ、対照的構成 一変化しているといえる。また、巻末の冬から冒頭の春一の移行を 比較すると、山水小巻では水平景から水平景への移行であるのに対 し、山水長巻では水平景の左端に山岳景の始まりを示寸懸崖が描か れており、これが春景の山岳の始まりを示す構成を見せ、山岳景と 水平景の対照が、季節の繰り返しの中により明瞭に位置づけられて いるといえる。これらの季節構成と空間構成類型の対応関係を照ら し合わせると、山水小巻の春夏景が山水長巻の春夏秋景に、山水小 巻の秋冬景が山水長巻の冬景に対応している。

全体を通してみると、山水小巻と山水長巻の類似点と相違点は次 


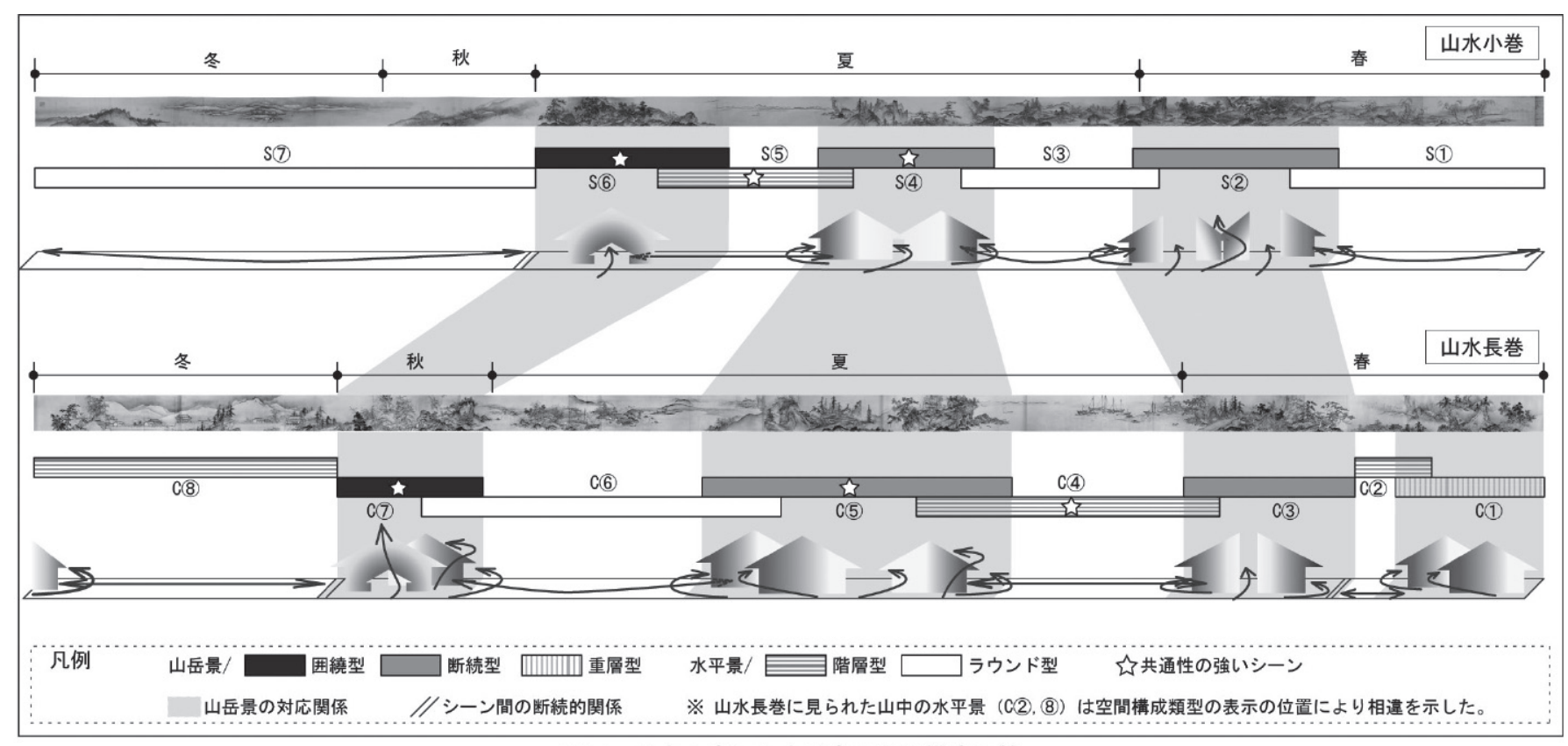

図 5 山水小巻と山水長巻の空間構成比較

の 3 点にまとめられる。

1. 山岳景と水平景の繰り返しによる構成という基本的構想、山岳 景の背後に水平景が連続するというシーン間の基本的な空間的 関係、山岳景の空間構成と全体に対する類型配置、以上 3 点は継 承される。

2. 水平景において水平性が強調されること、懸崖付近が立体化・明 瞭化することにより、山岳景と水平景がより対照的に構成される。

3. 季節構成では、山水小巻の夏景までが山水長巻の秋景までに対応 し、季節間の対照がますとともに季節の繰り返し表現が構築的に なる。

\section{5. 考察 : 巻子の空間構成と鑑賞}

これまで山水小巻と山水長巻を、山岳景と水平景というシーン区 分を手がかりに分析し、山水長巻では山水小巻の全体構成が踏襲さ れながらも、より構築的・対照的に構想されていることを明らかに してきた。巻子に限らず、当時の山水画は山水臥游といわれるよう に、人々が普段のあわただしい生活の中にあって、自然の中にある 本来の生を生きる契機になっていたと考えられている注 ${ }^{15)}$ 。対象と してきた $2 つ の$ 巻子は、いずれも冒頭に高士が童子を伴って右から 左へと歩みを進める姿が描かれており、山水画に臨む人は巻子を展 開させながら高士に自分を重㸚あわ、描かれた山水を体験すると 考えられている。

ここでは本稿の分析の出発点であるとともに、結論の骨格をなし ている山岳景と水平景について、鑑賞における山水の体験の様相を 検討する。つぎに、これまで鑑賞形式にまとまった見解を見ること ができない山水長巻の鑑賞について、山水小巻との間に見られた空 間構成の対応関係から考察を試みる。

山岳景と水平景の鑑賞 : まず山水小巻 ・ 山水長巻とも、水平景に該 当するシーン内においては、空間的な連続性を確認することが出来 る。全てのシーンにおいて地形は主に左右に連続する要素で構成さ れ、鑑賞者はこうした水平方向に連続する空間の中で、山水の姿に
沿ってこれを体験することになる。一方、山岳景は両側に懸崖等の 巨大な岩山の一部が示され、シーン内部には奥行きのある空間が構 成されていた。水平景と山岳景の接続部にあたる懸崖等は、地形の まとまりとしては山岳景に含めて捉えることが出来る。しかし、山 岳景における両側の懸崖部分とシーン内部に展開する奥行きのある 地形の間には、空間的な断絶関係が示唆されているように思われる。

つまり、ほとんどの懸崖は水平景の水際から立ち上がりその前面 には岩山が配されているが、これらは水平景の左右の広がりを境界 づけ、かつ水平景との空間的な連続性を示している。一方、懸崖等 の山岳景側は空白表現となり、水平景の境界をなしていた前面の岩 山は山岳景シーン内部では小川や滝など山中の岩山となっている。 画面構成という点からは強い違和感を伴うことなくシーンを展開さ せることが可能であるが、実際の地形の相違を考えると水平景と山 岳景の間、寸なわち懸崖部分には相当の空間的断絶が含まれている と考えられる。ほとんどの懸崖等には水平景側を回り込む道が設け られていたが、鑑賞者はこの道に沿って山中へと進み、空間的断絶 の後に、山岳景の中央部に描かれている場面に前後の空間的・時間 的連続性から切り離された場面として出会うのではないだろうか。

山岳景と水平景の対照は、単に空間構成の夕ならず、鑑賞者によ る山水の経験様態においても、水平景の連続的な空間・時間の体験 と、山岳景における断続的な空間・時間の体験という対照的な構成 として捉えることができる。両者をつなぐ懸崖等の表現は、こうし た観点からも巻子構成の要として理解できる注 ${ }^{16)}$ 。

山水長巻の鑑賞形式 : 山水小巻と山水長巻の全体構成は、実際の寸 法の相違、つまり鑑賞形式の相違が想定されるにもかかわらず、空 間構成という観点から比較すると多くの対応関係が見られた。両者 の縦幅には倍近い相違があり、空間構成が継承されていても描写の 密度には相違がある。しかし、山水長巻の構想において山水小巻の 鑑賞形式、つまり鑑賞者が自ら展開させる画面のプロポーションや 全体の構成に対寸る展開の様相も念頭に置かれていたという仮定に たてば、山水長巻の鑑賞幅もこれに対応させて考えられていた可能 
性を指摘できるだろう。つまり、山水小巻が鑑賞される縦幅 $21.5 \mathrm{~cm}$ に対し肩幅 60-70 cm はおよそ 1:3 の横長プロポーションであり、こ れを山水長巻に置き換えると、縦幅 $39.2 \mathrm{~cm}$ に対して約 $120 \mathrm{~cm}$ の鑑賞 幅となる注 17$)$ 。当時の鑑賞における所作については不明な点が多い が、この場合、自らが座したまま巻子を展開させるという形式とは 明らかに異なった鑑賞形式が想定されることになり、逆に山水長巻 において、少なくともこの一般的な鑑賞形式が念頭に置かれていな かった可能性も指摘できる。

むろん、両巻とも鑑賞幅は厳密なものではないし、同じ人物の同 じ形式による鑑賞であったとしても、手繰り方の微妙な変化により、 目の前に広がる山水のまとまりは無限に変化する。しかし、具体的 な展開が多様であったとしても、鑑賞においてそれらは巻子全体の 中に関連づけられるだろう。本稿で明らかにしてきた山岳景と水平 景の空間構成および山水経験様態の対照は、鑑賞者にとっての山水 の骨組みである同時に、制作者にとっても山水構想の中心的な手法 または形式であったのではないだろうか。これらの可能性を考察と して示し結とする。

\section{6. おわりに}

本稿では雪舟による 2 つ四季山水図巻をシーンの連続として 捉え直し、シーンの空間構成を手がかりとして巻子全体の空間構成 の特徴を明らかにしてきた。今後は、室町期に描かれた他の山水画 との比較を行うとともに山水画が担っていた文化的意義や社会的環 境をふまえ、当時の理想的風景の型について研究を進めていきたい。

\section{注}

注1）宮次男他編：角川絵巻物総覧，1995。美術史用語では巻子装の水墨山水 図は絵巻物に含まない

注2) 島田修二郎：禅林画賛, 毎日新聞社, 1987

注3）美術史の分野においては、雪舟の真筆如何が明確に提示されることはほ とんどない。本稿では雪舟の真筆および制作年代順については、次の論 文に従った。山下祐二：雪舟画の本質一逸脱について, 国華, 1276 号, pp. 19-32，2002。山水小巻については習作的性格から真筆としない見解 もあり、鑑定が難しい作品とされている。

注4）日明貿易等を通して日本へもたらされた山水画の多くは当時規範とし て扱われ模写を通して受容されるが、図卷構成においては、先行する作 品の部分をつなぎながら長大な構図を制作する手法がすでに中国にお いて伝統的に継承され、当時の日本においても理解されていたと考えら れている。夏珪による図巻の構成法については、小川裕充 : 宋元山水画 における構成の伝承, 美術史論業第 13 号, 東京大学大学院人文社会系 研究科・文学部美術史研究室, pp. 1-40，1997 年。雪舟による図様や意 味の継承については後述。

注5）山水長巻を雪舟の人生と重社合わせる理解は一般的で多くの概説書に 散見される。橋本治：わかりやすいもの雪舟筆「山水長巻」, ひらがな 日本美術史, 第 2 巻, 新潮社, 1997 年他。禅宗の理念と結びつけるもの としては、大橋良介：雪舟とヨーロッパー『山水長巻』における「自然」, 文化における

注6）夏珪による図巻との関連で山水小巻が扱われることがあるものの、本格 的な研究は行われていない

注7）東京国立博物館, 京都国立博物館編：雪舟：没後 500 年特別展, 毎日新 聞社, 2002.3

注8) 本研究では原寸大の複製を制作しこれを繰りながら研究方法の検討を 行った。山水長巻は肩幅程度の繰り幅では画面の展開が小刻夕に過ぎ、 付人等により画面が展開されこれを鑑賞した可能性も考えられる。

注9）図中におよその転換点を示した。山水長巻に関しては次の文献にもとづ いて確認した。島尾新 : 雪舟の「山水長巻」風景絵巻の世界で遊ぼう,
小学館，2001。山水小巻に関しては九州国立博物館、烟靖紀氏からご 教示頂いた。記して感謝したい。

注10）意味を伴う図様のまとまりについては、美術史の分野において詳細な 検討が行われている。継承の様態がまとめられているものとして次の 2 つの論文が挙げられる。山下裕二 : 夏珪と室町山水画, 室町絵画の 残像, 中央公論美術出版, pp. 12-31，2000。烟靖紀: 山水長巻研究-そ の<かたち $>$ と<意味>をめぐって, 天開圖畫, 2 号、雪舟研究会研究 誌，pp. 3-27，1998 年。畑による論文では、意味を伴うまとまりに対す る鑑賞者の理解等、作品をとりまく社会的な環境をふまえた鑑賞形式 一の言及も見られる。

注11）秋冬山水図（東京国立博物館所蔵、国宝）の冬景でも用いられている 有名なモチーフで、これがシーンのつなぎの役割を担っている可能性 は寸でに指摘されているが、巻子全体の骨格をな寸モチーフとして注 目されることはない（前掲注 $9, p p .82 \sim 83$ )。本稿で山岳景と水平景 の区分として注目する懸崖等 14 箇所のうち、11 箇所で岩山の一部が描 かれているが 10 箇所で下部が抉れた懸崖となっている。3 箇所では山 岳景中央部の岩山表現により両側に懸崖等の立ち上がりが示唆される。

注12）図 3,4 において構成要素の配置の様相はシーンで区分せず連続的に表 現し、主な構成要素のみを引き出し線で示した。また方向性の模式化 はシーンごとに行い、巨大な岩山による方向性を山岳景においてはグ ラデーションで、水平景においては点線で表した。

注13） C(5)の左端の部分は空間構成として C (1) と共通点が多いが、シーン全体 の構成という観点から C(5) は山岳景断続型に区分した。

注14）山水小巻では観瀑のシーン、山水長巻では山市晴嵐のシーンである。

注15）小野恭平 : 山水の楽・序説 : 中世詩画軸の題詩からみた, 日本建築学 会計画系論文集，第 551 号，pp. 321-327，2002.1 他。

注16）山水長巻は C11において主人公の高士達が山道を登る姿に始まるが、 すぐ後の C(3)において同じ高士達が橋を左から右へ、つまり巻子全体 の方向では、終わりから始まりに向けて歩を進めている。一見すると 強い違和感を抱く場面であり、高士が最後まで旅を続けるという期待 が裏切られると紹介されることがある。しかし、山中の一場面が前後 の連続性から切り離された形で示されているという理解にたてば、画 面構成上の左右に拘泥寸ることなく高士とともに旅を続けることがで きる。

注17）巻子全体では山水小巻の方が横長であるが、山水小巻の夏景までの構 成が、山水長巻の秋景までの構成に置き換えられていた。該当部のプ ロポーションがほぼ同じ（1:33）になっている点も注目される。

\section{図版出典}

図表中の山水小巻は京都国立博物館データベース、山水長巻は便利堂刊行 の絵巻物シリーズ四季山水図巻より引用の上加筆。その他図表中の図版は筆 者作成。

（2009年12月27日原稿受理，2010年 2 月23日採用決定） 